\title{
Macroscopic lithotype characterisation of the 1st Middle-Polish (1st Lusatian) Lignite Seam in the Miocene of central Poland
}

\author{
Marek Widera \\ Institute of Geology, Adam Mickiewicz University, Maków Polnych 16, 61-606 Poznań, Poland; \\ e-mail: widera@amu.edu.pl
}

\begin{abstract}
The 1st Middle-Polish (1st Lusatian) Lignite Seam is exploited in open-cast mines in central Poland. A large number of lignite lithotypes, grouped in four lithotype associations, are distinguished: xylitic, detritic, xylo-detritic and detroxylitic lithotype associations, which show various structures. Each lithotype association was produced under specific peat-forming environmental conditions. In the case of the lignite seams under study they represent all the main environments that are known from Neogene mires, i.e.: fen or open water, bush moor, wet forest swamp and dry forest swamp.

For a simple and practical description in the field of both the lignite sections and borehole cores, a new codification for lignite lithotypes is proposed. It is based on the codification of clastic deposits (lithofacies). The practical value of the new lignite lithotype codification is examined in three vertical sections of the 1st Middle-Polish Lignite Seam.
\end{abstract}

Keywords: lignite lithotypes, sedimentology, First Middle-Polish Lignite Seam, Miocene, central Poland

\section{Introduction}

The $1^{\text {st }}$ Middle-Polish ( $1^{\text {st }}$ Lusatian) Lignite Seam (MPLS-1) is exploited only in the surroundings of Konin and Turek. The Lubstów open-cast mine (Fig. 1), where the $2^{\text {nd }}$ Lusatian Lignite Seam has been extracted, was closed in 2009. The annual lignite production in this region is about $13-14$ million tones, and almost $100 \%$ is consumed by electrical power plants.

During the last 70 years, over 7000 boreholes have been drilled to document the lignite deposits in the study area (Widera, 2007; Widera et al., 2007). Moreover, every year additional boreholes are drilled for detailed petrographical analyses, and the walls of the excavations are also mapped. These activities require de- scriptions in a proper form, but this is complex and time-consuming without a proper lithotype codification. Previously used codes for lignite lithotypes were limited to textural features only (cf. Brzyski, 1981; Kwiecińska \& Wagner, 1997; Taylor et al., 1998; Markič et al., 2001).

\subsection{Objectives}

The main objective of the present contribution is to distinguish the lithotype compositions of the MPLS-1, which has been exploited because of its extensive presence in central Poland. The distinguishing between lithotypes should show the relationship between peat- 


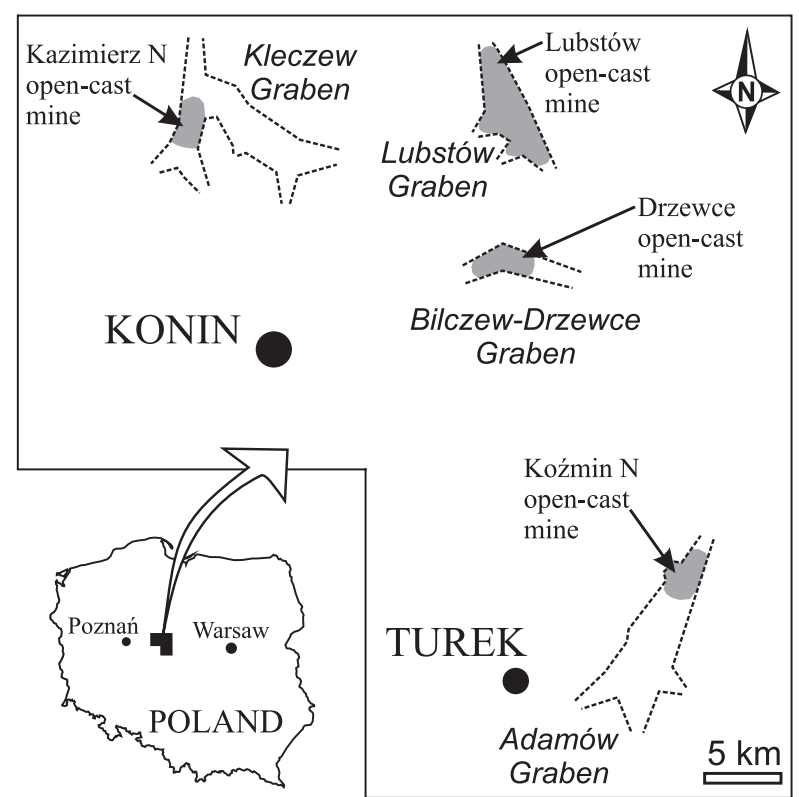

Fig. 1. Location map of the lignite open-cast mines in the grabens of the Konin-Turek area, central Poland.

forming environments and the resulting lignite lithotypes.

A new codification for lignite lithotypes has been developed for the purpose. It is based on the combination of textural and structural properties of the lignite seam. The proposed lithotype codes should be applicable in the field and during the documentation of sections of the lignite seam.

\subsection{Geological setting}

In central Poland, the major lignite deposits are located in grabens that were tectonically active in the Paleogene and/or Neogene (Kasiński \& Piwocki, 1992; Widera, 2007; Widera \& Hałuszczak, 2011). The lignites under study here are exposed in the Drzewce, Kazimierz $\mathrm{N}$ and Koźmin $\mathrm{N}$ open-cast mines, which occur in the Drzewce-Bilczew, Kleczew and Adamów grabens, respectively (Fig. 1). The Drzewce-Bilczew and Adamów grabens started their development at the Eocene/Oligocene boundary (Widera \& Kita, 2007; Widera, 2010). Since the Early Oligocene, the entire area of central Poland was subjected to uplift (Widera et al., 2008; Jarosiński et al., 2009; Widera \& Hałuszczak, 2011). In contrast, the Kle- czew Graben started to subside at the turn of the Oligocene/Miocene, as shown by the presence of Miocene sediments at the base of the succession (Widera, 2007).

In all cases the MPLS-1 is underlain by sands with intercalations of silts and lignites of Early-Middle Miocene age. The sands are thick: from a few decimetres to up $50 \mathrm{~m}$. The lignites of the MPLS-1 show an average thickness of 6.5-8.7 m (Sadowska \& Giża, 1991; Ważyńska, 1998). Their age is middle Middle Miocene (Piwocki \& Ziembińska-Tworzydło, 1997), so that they correlate in time with the $1^{\text {st }}$ Lusatian Lignite Seam of SE Germany (Standke et al., 1993; Grimm, 2002). The Polish lignite is a low-rank coal (reflectance, $\mathrm{Rr}=0.26-0.29 \%$; Kwiecińska \& Wagner, 1997, 2001) with an ash content of $11.0-12.0 \mathrm{wt} \%$ and a sulphur content of $0.8-0.9$ $\mathrm{wt} \%$. These properties of the lignites from the Konin-Turek region make them suitable as a cheap fuel for the production of electricity for decades (Piwocki, 1987; Kasiński et al., 2006; Bielowicz, 2010).

The MPLS-1 is overlain by fine-grained deposits, mainly clays and silts with lenses of fine sands. Their total thickness ranges from a few metres to more than $30 \mathrm{~m}$. They were probably deposited in an anastomosing-river environment (Widera, 2007) from the middle part of the Middle Miocene to the lowermost part of the Early Pliocene (Piwocki \& ZiembińskaTworzydło, 1997).

\section{Former nomenclature and codification of lignite lithotypes and lithofacies}

The currently used lignite lithotype terminology and classification is highly complex (cf. Brzyski, 1981; Markič et al., 2001) and differs from the ICCP (1993) recommendations (Taylor et al., 1998). Until now the term 'lithotype' has been used in textural descriptions of lignites. In a sedimentological sense, however, a lignite lithotype is a macroscopically recognisable and homogeneous stratum of lowrank coal with a thickness of more than $5 \mathrm{~cm}$ (Kwiecińska \& Wagner, 1997; Ticleanu et al., 
Table 1. Codes for the main lignite lithotypes according to Kolcon \& Sachsenhofer (1999).

\begin{tabular}{|cc}
\hline lithotype & code \\
\hline xylitic coal & $\mathrm{X}$ \\
detritic coal & $\mathrm{D}$ \\
\hline detro-xylitic coal & $\mathrm{D}-\mathrm{X}$ \\
xylo-detritic coal & $\mathrm{X}-\mathrm{D}$ \\
fusitic coal & $\mathrm{F}$ \\
\hline
\end{tabular}

Table 2. Codes for the main lignite lithotypes according to Ticleanu et al. (1997).

\begin{tabular}{cc}
\hline lithotype & code \\
\hline coal & $\mathrm{XC}$ \\
\hline detrital coal & $\mathrm{DC}$ \\
\hline weak coal & $\mathrm{WXC}$ \\
clayey coal & $\mathrm{CC}$ \\
charcoal & $\mathrm{CH}$ \\
\hline
\end{tabular}

1999). Two lithotype codifications, which are still the most popular, are presented in Tables 1 and 2. These codes are applicable to lignite seams only. Much confusion is therefore raised when sections containing both lignite seams and associated clastic deposits are described.

The lithofacies code for the description of sediments that was established by Miall (1977) and then slightly modified (e.g. Eyles et al., 1983; Ghibaudo, 1992; Rhee \& Chough, 1993; Mastalerz, 1995; Zieliński, 1995; Krüger \& Kjær, 1999), is widely used. This code consists of letter symbols for grain size (e.g. G denotes gravel, $\mathrm{S}=$ sand, $\mathrm{F}=$ fines = silt + clay, $\mathrm{D}=$ diamict, $\mathrm{C}=$ organic deposits, etc.) and structure $(\mathrm{m}=$ massive, $\mathrm{h}=$ horizontally stratified, $\mathrm{p}=$ planar cross-stratified, $\mathrm{d}=$ deformed, etc.). For example, the lithofacies Gh and GSh can be denoted as horizontally stratified gravel and horizontally stratified sandy gravel, respectively.

A problem arises, however, when the lithotype nomenclature and lithofacies codes are used together. The ' $F$ ' code can refer to 'fusitic coal' in the lignite lithotype codification (Table 1; Kolcon \& Sachsenhofer, 1999) or can be identified as 'fines', i.e. silt and clay, in the lithofacies codification (Miall, 1977). Similarly, the ' $\mathrm{D}$ ' code can mean 'detritic coal' in the lignite lithotype codification (Table 1; Markič \& Sachsenhofer, 1997) or can be identified as 'diamict' in the lithofacies codification (Eyles et al., 1983). To avoid any possible confusion between these codes, a new codification of lignite lithotypes is therefore proposed.

\section{Proposed nomenclature and codification of lignite lithotypes}

A change of the definition of the term 'lithotype' is proposed. A term that is well applicable in practice should describe - as done in the lithofacies nomenclature (Miall, 1977) - both textural and structural features of lignite. The term 'lignite lithotype' should therefore refer to a macroscopically recognisable and homogeneous stratum of low-rank coal (lignite) with a thickness of more than $5 \mathrm{~cm}$, which is characterised by a specific texture and structure.

The most adequate for the lignite texture is the nomenclature established by Wolf (1988), and then adapted and widely propagated by Markič \& Sachsenhofer (1997) and Kolcon \& Sachsenhofer $(1998,1999)$. The codes for the lignite texture, used by these authors, should, however, be changed for the above reasons (Table 1). It is proposed here to use the capital letters: X (for xylitic), D (for detritic), XD (for xylo-detritic), DX (for detro-xylitic), and F (for fusitic), always in combination with a capital letter L (lignite). For example, the 'XDL' code refers to a 'xylo-detritic lignite' texture in this lignite lithotype codification (Table 3).

Moreover, the internal structure of lignite should be coded with lower-case letters, again following the sedimentary lithofacies codification. Field experience shows that four letters are enough for the basic description of the lignite structure. Appropriate lower-case letters for the structure of lignites are: $m$ (for massive), $h$ (for horizontally stratified), $\mathrm{g}$ (for gelified), and d (for deformed). Deformed lignite can be coded by two extra letters (between brackets) to indicate the type of deformation: (fr) for fractured, (fa) for faulted, and (fo) for folded. For example, code 'XLm' refers to the 'xylitic lignite with a massive structure' code 'DLd(fo)' indicates a 'detritic lignite with a deformed (folded) structure' (Table 3). 
Table 3. Proposition for a new lignite-lithotype codification (nomenclature partly by Wolf, 1988).

\begin{tabular}{cc}
\hline lithotype texture & code \\
\hline xylitic lignite & $\mathrm{XL}$ \\
\hline detritic lignite & $\mathrm{DL}$ \\
\hline detro-xylitic lignite & $\mathrm{DXL}$ \\
xylo-detritic lignite & $\mathrm{XDL}$ \\
\hline fusitic lignite & $\mathrm{FL}$ \\
\hline & \\
\hline lithotype structure & code \\
\hline massive & $\mathrm{m}$ \\
\hline horizontally stratified & $\mathrm{h}$ \\
\hline deformed (fractured, folded, faulted) & $\mathrm{d}(\mathrm{fr}, \mathrm{fo}, \mathrm{fa})$ \\
\hline gelified & $\mathrm{g}$ \\
\hline
\end{tabular}

\section{General description of the lignite lithotype associations}

The classification of the lignite lithotypes is based on a quantitative criterion, the so-called ' $10 \%$ rule'. It is used by most scientists and also recommended by the ICCP (1993). The content of such a lignite-seam elements is taken into consideration as xylitic fragments, fine-detrital matrix and/or fusitic particles (e.g. Wolf, 1988; Kwiecińska \& Wagner, 1997; Markič \& Sachsenhofer, 1997; Taylor et al., 1998; Kolcon \& Sachsenhofer, 1998, 1999). Obviously, each of described lithotypes may represent several possible combinations of structures in the codes listed below (cf. Table 3).

\subsection{Xylitic lignite $(X L)$ association}

This lignite lithotype association contains at least $90 \%$ of xylites, i.e. well fossilized wood fragments such as stumps, trunks and branches. They must be larger than $1 \mathrm{~cm}$ and, therefore, the interior structure of wood is macroscopically well visible. The matrix of this lithotype association consists of fine-detrital $(<1 \mathrm{~cm})$ matter. In most cases the xylites lay horizontally (e.g. trunks, branches, twigs), but sometimes they are in growth position (e.g. stumps, roots). For this lithotype association, all structures (i.e. massive, horizontally stratified, gelified and deformed) are characteristic and included in the lignite lithotype codification presented here (Table 3).

\subsection{Detritic lignite (DL) association}

This association consists of more than $90 \%$ of fine-graded $(<1 \mathrm{~cm})$, usually homogeneous organic matter. The rest (up to $10 \%$ ) of the components are xylitic fragments. Detritic lignite is mostly characterised by a massive and/or deformed structure, e.g. with cleat-like fractures (Fig. 2), but sometimes it can be horizontally or pseudo-horizontally stratified. A gelified structure is sporadically present in detritic lignite.

\subsection{Xylo-detritic lignite (XDL) and detro- xylitic lignite (DXL) associations}

These two lithotype associations are a combination of both the xylitic and detritic ones. They have various structures. Paradoxically, it has been historically established that xylo-

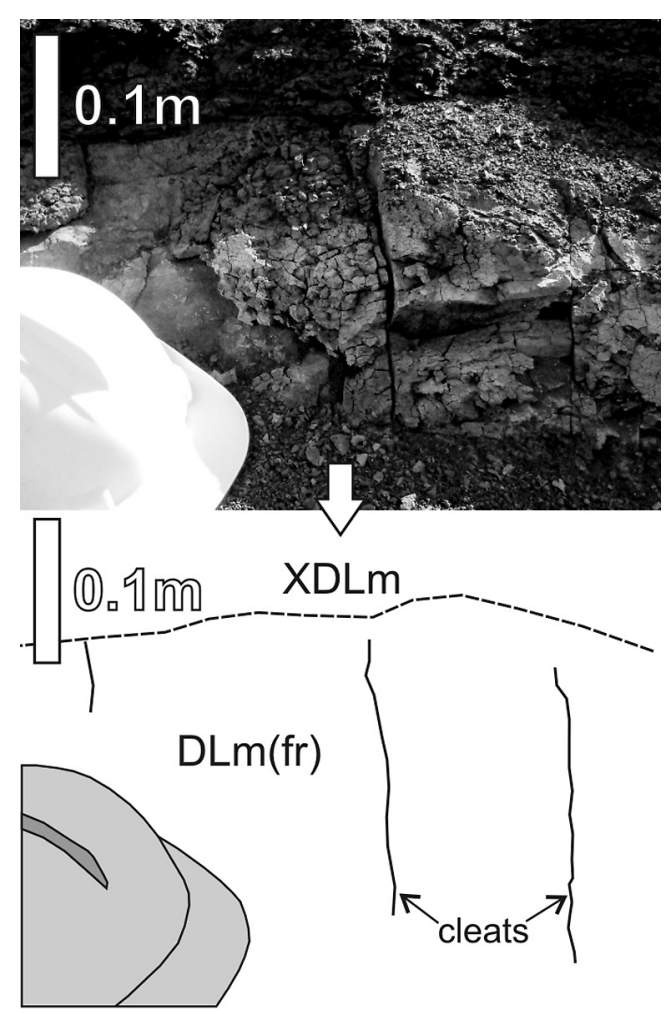

Fig. 2. Fractures developed within the xylo-detritic lignite lithotype (Kazimierz N open-cast mine). For explanation of the lignite lithotype codes, see Table 3. 
detritic lignite contains more detrital matrix than xylites. In contrast, the detro-xylitic lignite comprises more xylitic particles than the surrounding fine-detrital matrix (cf. Brzyski, 1981; Wolf, 1988; Kwiecińska \& Wagner, 1997; Markič \& Sachsenhofer, 1997; Taylor et al., 1998; Kolcon \& Sachsenhofer, 1999; Markič et al., 2001). On the other hand, the sum of the xylites and detrital matrix should be more than $90 \%$ (the ' $10 \%$ rule' - in the described two lignite lithotypes). These lithotype associations

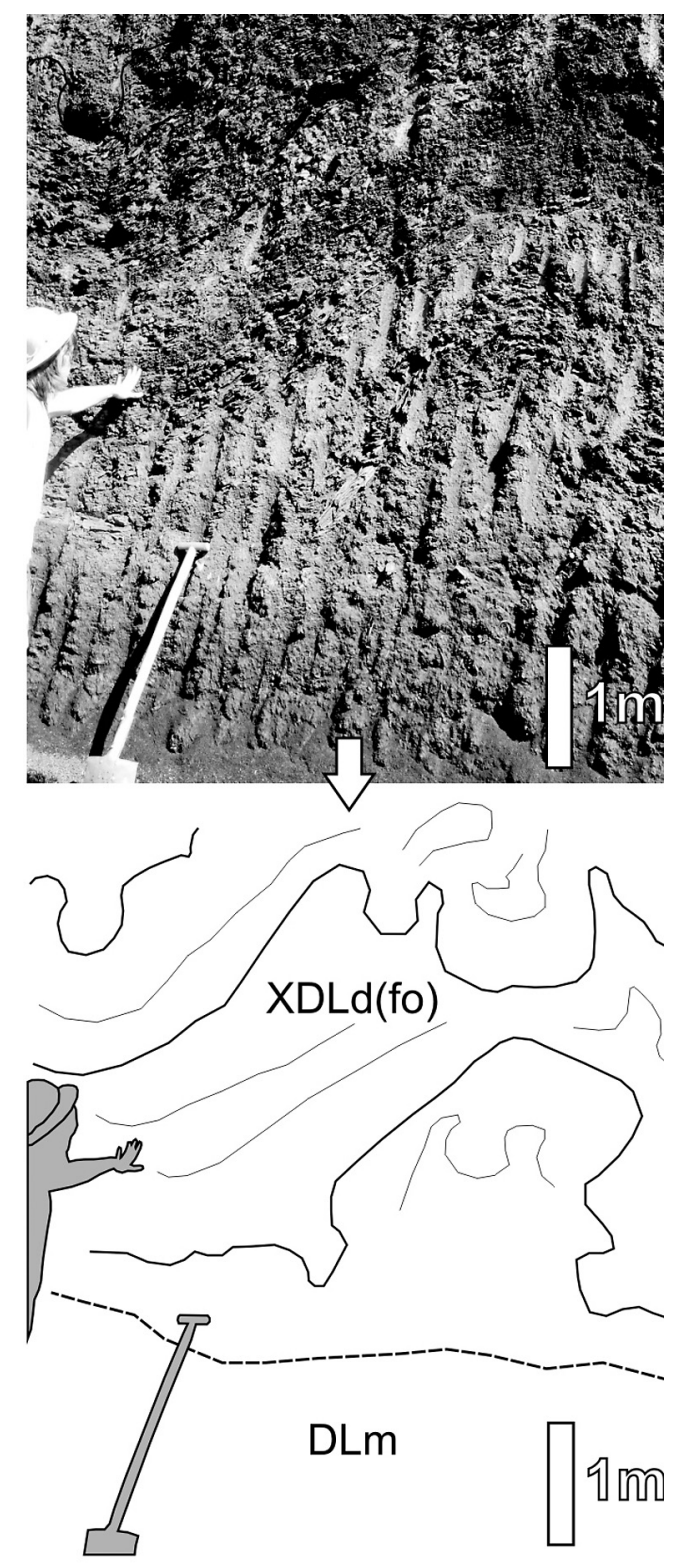

Fig. 3. Folds in the xylo-detritic lignite lithotype (Drzewce open-cast mine). For explanation of the lignite lithotype codes, see Table 3. represent all structures included in Table 3, e.g. a folded structure (Fig. 3).

\subsection{Fusitic lignite with massive structure (FLm) association}

The presence of the fusitic lignite association in a lignite seam indicates that fires happened in a mire (e.g. Kwiecińska \& Wagner, 1997; Ticleanu et al., 1999). Fusitic lignite is actually a fossil charcoal; it is, therefore, relatively rare in a lignite-seam profile. Fusitic lignite is most commonly a part of other lithotypes. It forms lenses rather than continuous strata, or it occurs as encrustations around xylites. This lithotype association is black or silky-black, highly porous and friable, with needle-shaped particles (Wolf, 1988; Markič \& Sachsenhofer, 1997; Kolcon \& Sachsenhofer, 1999). The macroscopically visible structure can consequently only be massive.

\section{Macroscopic description of the lignite seam under study}

The characteristics of the MPLS-1 can be studied in three vertical sections from the lignite open-cast in the surroundings of Konin and Turek, viz. Kazimierz N, Drzewce and Koźmin N (Fig. 1).

\subsection{The Kazimierz N site}

The Kazimierz $\mathrm{N}$ section is exposed in the northern part of the Kazimierz $\mathrm{N}$ open-cast mine. It belongs to the western, S-N-trending branch of the Kleczew Graben, located $\sim 20 \mathrm{~km}$ NNW of Konin (Fig. 1). The altitude of this section ranges between 44.2 and $52.2 \mathrm{~m}$ a.s.l., and the thickness of its lignite seam is $7.7 \mathrm{~m}$ only (Fig. 4).

Four lignite lithotypes associations and two lithofacies ones have been distinguished (Fig. 4). The latter comprise (1) lithofacies association Fm, Sm, and (2) lithofacies association Sh, Shd(fa). They represent the clastic deposits that, respectively, underlie and overlie the lig- 


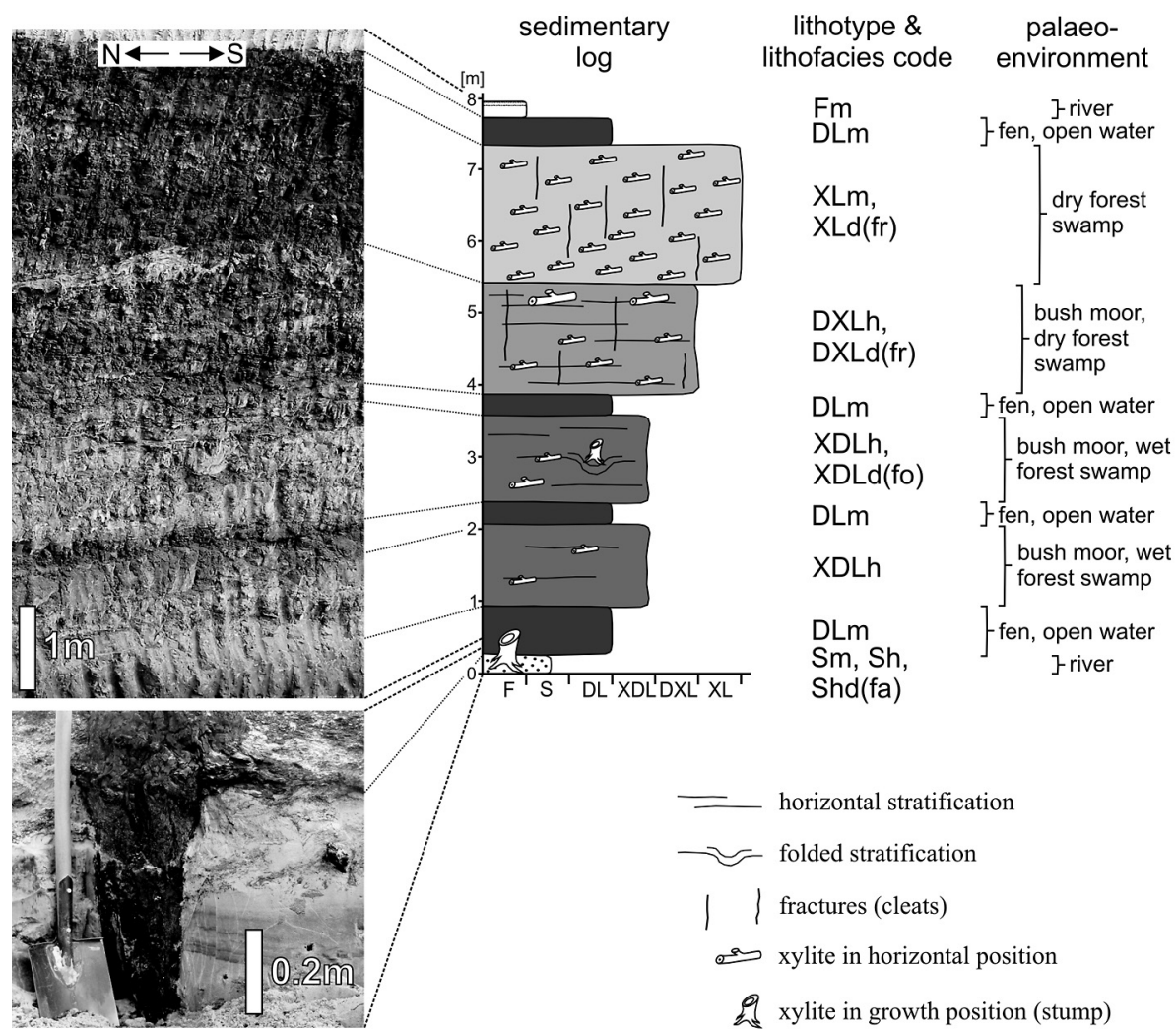

Fig. 4. Macroscopic vertical section of the $1^{\text {st }}$ Middle-Polish Lignite Seam in the Kazimierz N open-cast mine. Note the shallowing-upward trend characterised by a transition from detritic lignite at the base to xylitic lignite at the top. For explanation of the lignite lithotype codes, see Table 3; for explanation of the lithofacies codes, see the text.

nite seam. On the other hand, four lignite lithotype associations consist of one or two lignite lithotypes.

The section starts with detritic lignite with a massive structure, i.e. DLm, which is $0.7 \mathrm{~m}$ thick. Moreover, two layers of this lithotype are also situated between other lithotypes or lithotype associations: XDLh and XDLh, XDLd(fo) as well as XDLh, XDLd(fo) and DXLh, DXLd(fr) (cf. Table 3). The thickest (up to $1.8 \mathrm{~m}$ ) lithotype association, consisting of lithotypes XLm or $\mathrm{XLd}(\mathrm{fr})$, is exposed in the upper part of the section. The section ends with detritic lignite with a massive structure, i.e. DLm, which is 0.3 $\mathrm{m}$ thick (Fig. 4).

Most of the lignite lithotypes are deformed (folded and/or fractured): XDLd(fo), DXLd(fr) and $\mathrm{XLd}(\mathrm{fr})$. Additionally, the presence of the xylites in growth position is also very characteristic in the vertical section of the lignite seam (Fig. 4).

\subsection{The Drzewce site}

This lignite section is situated in the centralnorthern segment of the Drzewce open-cast mine. It occurs in the axial part of the W-E trending Bilczew-Drzewce Graben, which is located $\sim 15 \mathrm{~km}$ ENE of Konin (Fig. 1). The altitude of the section ranges from $61.8 \mathrm{~m}$ to $68.8 \mathrm{~m}$ a.s.l. The lignite seam is $6.6 \mathrm{~m}$ thick (Fig. 5).

A clastic lithofacies association underlies the lignite seam and is composed of massive as well as horizontally stratified sand, i.e. Sm and Sh. The lignite seam contains five lithotypes, which can be grouped in four lignite lithotype associations (Fig. 5). The horizontally stratified xylo-detritic lignite lithotype, XDLh, is the lowermost in the section. It is overlain by a $2.1 \mathrm{~m}$ thick lithotype of xylitic lignite with a slightly folded structure $\mathrm{XLd}$ (fo). Two layers of massive detritic lignite, DLm, follow, with intercalation of a xylitic horizon, XLm, of 0.2-0.3 thick. A detro-xylitic lignite with folded structure, DXLd(fo), forms the top part of the 

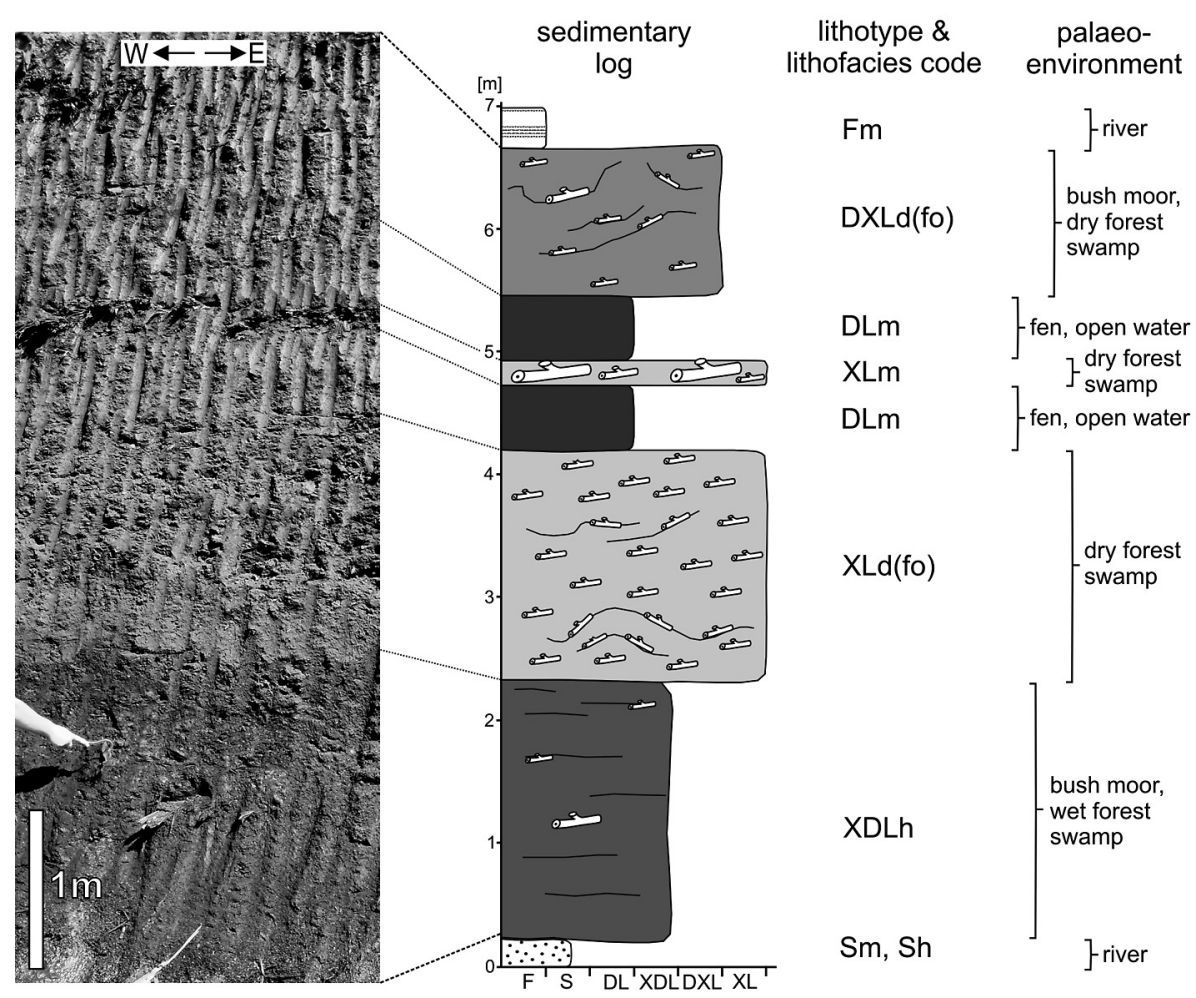

Fig. 5. Vertical section of the $1^{\text {st }}$ Middle-Polish Lignite Seam in the Drzewce open-cast mine. Note the presence of lithotypes with a large xylites content in the middle of the section. For explanation of the lignite lithotype codes, see Table 3; for explanation of the lithofacies codes, see the text; for graphic explanations, see Figure 4.

lignite seam. Massive fines (silt + clay), Fm, overlie the lignite seam in the section (Fig. 5).

\subsection{The Koźmin N site}

This section is located in the northern part of the Koźmin N open-cast mine, which is situated in the Adamów Graben. This SSW-NNE trending tectonic structure is located $5-20 \mathrm{~km}$ $\mathrm{E}$ and NE of Turek (Fig. 1). The altitude of the presented section ranges between 57.3 and 64.0 $\mathrm{m}$ a.s.l. The lignite seam is $6.2 \mathrm{~m}$ thick (Fig. 6).

Massive sand and/or fines (silt + clay) with a much organic matter, SCm and FCm, lay at the base of the section; it is noteworthy that xylites in growth position are very common in the clastic deposits under the lignite seam (Fig. 6). Then follows the lignite-bearing part, in which only three lignite lithotype associations are present (Fig. 6). The xylo-detritic lignite lithotype association, XDL, dominates; it shows various structures: XDLm, XDLh, XDLd(fr) and XDLd(fo). The layers belonging to this association jointly are $5.0 \mathrm{~m}$ thick. Ad- ditionally, massive detritic lignite, DLm, and fractured detro-xilitic lignite, DXLd(fr), are present in the middle part of the lignite seam (Fig. 6). Massive fines, Fm, rest at the top of the section.

\section{Interpretation and discussion}

The MPLS-1 in central Poland is underlain and overlain by clastic sediments (Figs 4-6). Taking into consideration the depositional architecture, palaeogeographical position and lithofacies assemblages, these clastic deposits are characteristic of a river environment. The sediments under the lignite represent an alluvial fan and braided river, whereas those on top of the seam are characteristic of an anastomosing river (Widera, 2007, 2010).

The reconstruction of a mire type and resulting lignite lithotypes (Fig. 7) has been based on the pioneering studies by Teichmüller (1958). The relationship between the peat-forming environment and lignite lithotypes has been discussed by Wolf (1988), Teichmüller (1989), 

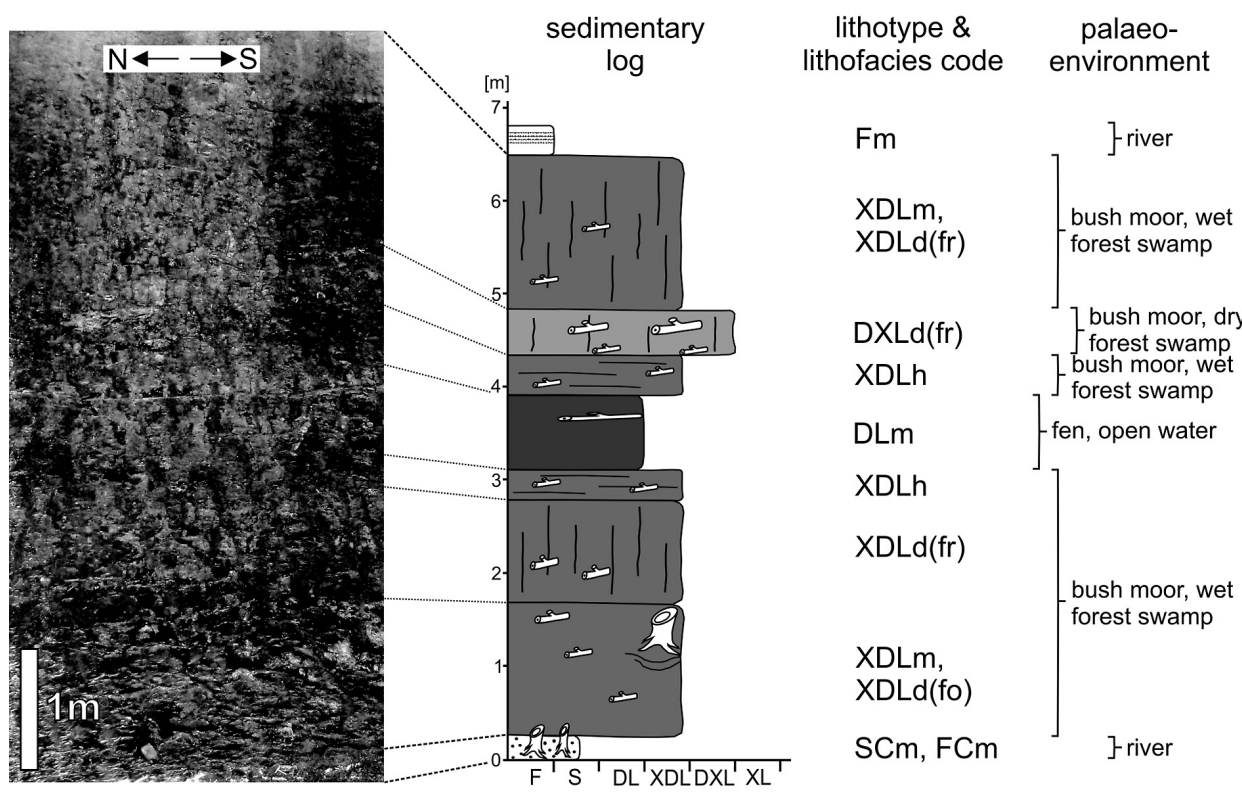

Fig. 6. Macroscopic vertical section of the $1^{\text {st }}$ Middle-Polish Lignite Seam in the Koźmin N open-cast mine. Note the fold (lower-right corner of the section) formed by the weight of tree. For explanation of the lignite lithotype codes, see Table 3; for explanation of the lithofacies codes, see the text; for graphic explanations, see Figure 4.

Kwiecińska \& Wagner (1997), Markič \& Sachsenhofer (1997), Kolcon \& Sachsenhofer (1999), Lücke et al. (1999), Ticleanu et al. (1999), Diessel et al. (2000), Markič et al. (2001), and others.

The first lithotype association is composed of one lignite lithotype, DLm (detritic lignite with massive structure). This lithotype is used as the prototype of a fen or open-water environment (Fig. 7). It may be related to a treeless reed marsh in the terminology of Teichmüller (1958, 1989). The sedges and reed-like vegetation as well as the aquatic plants should be regarded as the parent material for this lignite lithotype (Kolcon \& Sachsenhofer, 1999; Ticleanu et al., 1999).

The second lithotype association, DXLh, DXLd(fr) and DXLd(fo), is characteristic of a wet forest swamp (Fig. 7). This type of a mire is also called the Taxodium-Nyssa swamp (Teichmüller, 1958, 1989). During the formation of this kind of mire the stable water table was relatively high above the mire surface (e.g. Lücke et al., 1999; Diessel et al., 2000). On the other hand, the xylites in growth position, mainly produced by a gymnosperm forest, point at a dry phase in the mire evolution (Kolcon \& Sachsenhofer, 1999; Ticleanu et al., 1999).
The third lithotype association, XDLh and XDLd(fo), refers to a bush moor (e.g. Kolcon \& Sachsenhofer, 1999; Fig. 7). It is also addressed as a Myricaceae-Cyrillaceae swamp (Teichmüller, $1958,1989)$. The peat-forming conditions were slightly drier than in the two above-mentioned associations (e.g. Lücke et al., 1999). During the formation of this lithotype association, the bushy plants occupied the wet areas (Kolcon \& Sachsenhofer, 1999; Ticleanu et al., 1999).

The fourth lithotype association, XLm, $\mathrm{XLd}(\mathrm{fr})$ and $\mathrm{XLd}(\mathrm{fo})$, represents the dry forest swamp (Fig. 7). Taking into consideration the important role of Sequoia, this mire was named by Teichmüller (1958) a 'Sequoia swamp'. These lithotypes, i.e. xylitic lignites with various structures, are the best record of dry conditions in the mire history. When they formed, the water table was relatively deep below the mire surface (e.g. Lücke et al., 1999; Diessel et al., 2000).

The occurrence of the above mire types in the MPLS-1 is partially supported by plant assemblages. The dry forest swamp is characterised, for example, by pollen of Sequoia, Sciadopitys, Pinus, Betula and Fagus (Sadowska \& Giża, 1991; Ważyńska, 1998). In contrast, 


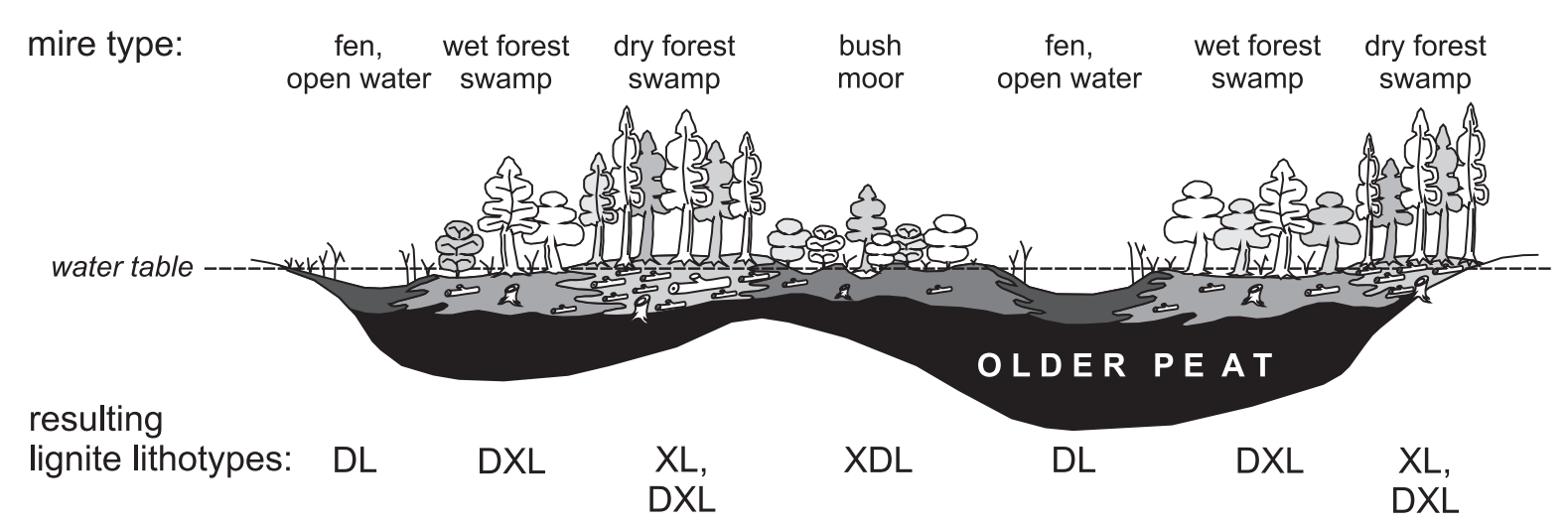

Fig. 7. Mire types and resulting lignite lithotypes for the $1^{\text {st }}$ Middle-Polish Lignite Seam in central Poland (modified after a model of Teichmüller, 1958, 1989). For explanation of the lignite lithotype codes, see Table 3; for graphic explanations, see Figure 4.

a predominance in the pollen spectrum of, for instance, Taxodium, Nyssa and Alnus indicates a wet forest swamp. Moreover, the depositional environment determined by Cyrillaceae, Myricaceae, Ericaceae, etc., is typical of a bush moor (Sadowska \& Giża, 1991; Ważyńska, 1998).

It is noteworthy that the contact between the lignite seam and the overlying clastic deposits is always sharp (Figs 4-6). This may be a result of sudden changes in the depositional conditions, i.e. from a limnotelmatic or telmatic to a fluvial or fluviolacustrine environment (Piwocki \& Ziembińska-Tworzydło, 1997; Widera, 2007). In contrast, the base of the lignite seam is sometimes gradual, e.g. in the Nazimierz $\mathrm{N}$ and Koźmin N sections. This may be explained by the presence of autochthonous stumps and small roots in the uppermost parts of the clastic deposits under the lignite seam (Figs 4, 6).

The MPLS-1 in central Poland developed while a land (fluvial environment) was replaced by a mire (limnotelmatic or telmatic environments). This transition process is called 'paludification' (Diessel et al., 2000). However, the lignite sections differ in detail. The lignite seam from the Nazimierz $\mathrm{N}$ mine, for example, shows a drying-and shallowing-upward trend. It is characterised by the lithotype transition from massive detritic lignite (DLm) to massive xylitic lignite (XLm) (Fig. 4). In contrast, a clear upward trend, showing either drying or wettening, is not traceable in the other lignite sections. This is shown, for example, in the Drzewce and Koźmin $\mathrm{N}$ sections, where the driest xylitic lithotypes with various structures, i.e. $\mathrm{XLd}(\mathrm{fo})$ and $\mathrm{XLm}$, are present in the middle part of the lignite seams (Figs 5-6).

Deformational structures such as folds and fractures are also common in the MPLS-1 in central Poland. The folds within the lignite seams may be interpreted in at least three ways. They can have been formed by tectonics (e.g. Ticleanu et al., 1999), by compaction (e.g. Widera et al., 2007) and due to the weight of trees. In the last-mentioned case, the folds were caused by the weight of peat-forming trees (Figs 3-5). The fractures in the lignite seams are interesting and important structures for the mining activity (Figs 2, 4, 6). Their origin is still under discussion, but commonly they are attributed to a combination of tectonic and diagenetic processes (Laubach et al., 1998).

On the basis of all above-mentioned lignite properties (lithotypes, thickness, ash content, tectonic background, etc.) a depositional model of the MPLS-1 can be discussed. The development of the mires occurred in tectonics-induced subsidence (Widera, 2007; Widera et al., 2007). On the other hand, the lithotype associations, the plant assemblages and the ash content $(>10 \%)$ point at low-lying mires according to McCabe (1984) or to topogenous, rheotrophic mires according to Diessel et al. (2000). Such mire areas probably were periodically covered by shallow $(<2 \mathrm{~m})$ water (Diessel et al., 2000). This is supported by the presence of the detritic lithotypes in the various sections (Figs 4-6). 


\section{Conclusions}

The lithotype composition of the $1^{\text {st }}$ MiddlePolish ( $1^{\text {st }}$ Lusatian) Lignite Seam (MPLS-1) was investigated on the basis of three vertical sections in open-cast mines in central Poland. Each of these mines is located in a graben, which subsided during the development of the mires in the Middle Miocene.

Each lithotype shows specific physical and chemical properties which reflect the depositional environment.

Four lignite lithotype associations have been identified in the MPLS-1. They are the detritic, the xylo-detritic, the detro-xylitic and the xylitic associations, each with various individual structures. Each of them may be related to at least one mire type: fen or open water, bush moor, wet forest swamp and dry forest swamp, respectively (Fig. 7). The sections under study show that the mires formed as a result of paludification.

The investigation of lignite seams requires practical and unambiguous descriptions of the lithotypes in the field. A new and more tight codification of lignite lithotypes is therefore proposed here. The proposed codes for lignite lithotypes can be applied together with those for lithofacies, in the same way as currently commonly done for sedimentological descriptions.

\section{Acknowledgements}

The Konin Lignite Mine and the Adamów Lignite Mine are kindly thanked for permission to conduct field work in their lignite open-cast mines. I express my sincere gratitude to the staff of the Departments of Geology from both mines for their hospitality and help in the field. Prof. A. Schäfer (Bonn, Germany) and an anonymous reviewer are gratefully acknowledged for providing valuable suggestions, which improved a previous version of the manuscript.

\section{References}

Bielowicz, B., 2010. New technological classification of lignite as a basis for balanced energy management. Gospodarka Surowcami Mineralnymi 26, 25-39.
Brzyski, B., 1981. Klasyfikacja megaskopowa i charakterystyka odmian trzeciorzędowego węgla brunatnego z obszaru Polski [Macroscopic classification and description of Tertiary brown coal varieties from the Polish territory]. Geologia 7, 5-30.

Diessel, C., Boyd, R., Wadsworth, J., Leckie, D. \& Chalmers, G., 2000. On balanced and unbalanced accommodation/peat accumulations ratios in the Cretaceous coals from Gates Formation, Western Canada, and their sequence-stratigraphic significance. International Journal of Coal Geology 43, 143-186.

Eyles, N., Eyles, C.H. \& Miall A.D., 1983. Lithofacies types and vertical profile models - an alternative approach to the description and environmental interpretation of glacial diamict and diamictite sequences. Sedimentology 30, 393-410.

Ghibaudo, G., 1992. Subaqueous sediment gravity flow deposits: practical criteria for their field description and classification. Sedimentology 39, 423-454.

Grimm, K. (Ed.), 2002. Tertiary. [In:] German Stratigraphic Commission (Ed.): Stratigraphic table of Germany 2002.

ICCP (International Committee for Coal Petrology), 1993. International handbook of coal petrography, $3^{\text {rd }}$ Supplement to $2^{\text {nd }}$ edition. University of Newcastle upon Tyne, England.

Jarosiński, M., Porawa, P. \& Ziegler, P.A., 2009. Cenozoic dynamic evolution of the Polish Platform. Geological Quarterly 53, 3-26.

Kasiński, J. \& Piwocki, M., 1992. Miocene coal-bearing basins of the Konin lignite deposits. [In:] Lützner (Ed.): $13^{\text {th }}$ IAS Regional Meeting of Sedimentology. Schiller University, Jena, 65-67.

Kasiński, J., Mazurek, S. \& Piwocki, M., 2006. Waloryzacja i ranking złóż węgla brunatnego w Polsce [Valorization and ranking list of lignite deposits in Poland]. Prace Państwowego Instytutu Geologicznego 187, 79 pp.

Kolcon, I. \& Sachsenhofer, R.F., 1998. Coal petrography and palynology of the Early Miocene lignite seam from the opencast mine Oberdorf ( $\mathrm{N}$ Voitsberg, Styria, Austria). [In:] F.F. Steininger (Ed.): The Early Miocene lignite deposits of Oberdorf, N Voitsberg (Styria, Austria). Jahrbuch der Geologischen Bundesanstalt 140, 433-440.

Kolcon, I. \& Sachsenhofer, R.F., 1999. Petrography, palynology and depositional environments of the Early Miocene Oberdorf lignite seam (Styrian Basin, Austria). International Journal of Coal Geology 41, 275-308.

Krüger, J. \& Kjær, K.H., 1999. A data chart for field description and genetic interpretation of glacial diamicts and associated sediments with examples from Greenland, Iceland, and Denmark. Boreas 28, 386-402.

Kwiecińska, B. \& Wagner, M., 1997. Typizacja cech jakościowych węgla brunatnego z krajowych złóż wedtug kryteriów petrograficznych $i$ chemiczno-technologicznych dla celów dokumentacji geologicznej złóż oraz obstugi kopalń [Classification of qualitative features of brown coal from Polish deposits according to petrographical, chemical and technological criteria]. Polish Academy of Sciences, Cracow, $87 \mathrm{pp}$.

Kwiecińska, B. \& Wagner, M., 2001. Możliwość zastosowania refleksyjności jako metody badawczej w klasyfikowaniu 
i technologicznej ocenie jakości węgla brunatnego [Application of reflectance in the natural and technological classification of brown coal]. University of Science and Technology Press, Cracow, 35 pp.

Laubach, S.E, Marrett, R.A., Olson, J.E. \& Scott, A.R., 1998. Characteristics and origins of coal cleat: a review. International Journal of Coal Geology 35, 175-207.

Lücke, A., Helle, G., Schleser, G.H., Figueiral, I., Mosbrugger, V., Jones T.P. \& Rowe, N.P., 1999. Environmental history of the German Lower Rhine embayment during the Middle Miocene as reflected by carbon isotopes in brown coal. Palaeogeography, Palaeoclimatology, Palaeoecology 154, 339-352.

Markič, M. \& Sachsenhofer, R.F., 1997. Petrographic composition and depositional environments of the Pliocene Velenje lignite seam (Slovenia). International Journal of Coal Geology 33, 229-254.

Markič, M., Zavšek, S., Pezdič, J., Skaberne, D. \& Kočevar, M., 2001. Macropetrographic characterization of the Velenje lignite (Slovenia). Acta Universitatis Carolinae, Geologica 45, 81-97.

Mastalerz, K., 1995. Deposits of high-density turbidity currents on fan-delta slopes: an example from the upper Visean Szczawno Fm., Intrasudetic Basin, Poland. Sedimentary Geology 98, 121-146.

McCabe, P.J., 1984. Depositional models of coal and coalbearing strata. [In:] R.A. Rahmani \& R.M. Flores (Eds): Sedimentology of coal and coal-bearing sequences. International Association of Sedimentologists Special Publication 7, 13-42.

Miall, A.D., 1977. A review of the braided-river depositional environment. Earth-Science Reviews 13, 1-62.

Piwocki, M., 1987. Chemiczne i technologiczne właściwości głównych trzeciorzędowych grup pokładów węgla brunatnego w Polsce [Chemical and technological properties of the main groups of Tertiary brown coal seams in Poland]. Biuletyn Instytutu Geologicznego 357, 41-60.

Piwocki, M. \& Ziembińska-Tworzydło, M., 1997. Neogene of the Polish Lowlands - lithostratigraphy and pollen-spore zones. Geological Quarterly 41, 21-40.

Rhee, C.W. \& Chough, S.K., 1993. The Cretaceous Pyonghae sequence, SE Korea: terminal fan facies. Palaeogeography, Palaeoclimatology, Palaeoecology 105, 139-156.

Sadowska, A. \& Giża, B., 1991. Flora i wiek węgla brunatnego $\mathrm{z}$ Pątnowa [The flora and age of the brown coal from Pątnów]. Acta Palaeobotanica 31, 201-214.

Standke, G., Rascher, J. \& Strauss, C., 1993. Relative sealevel fluctuations and brown coal formations around the Early-Middle Miocene boundary in the Lusatian brown coal district. Geologische Rundschau 82, 295305.

Taylor, G.H., Teichmüller, M., Davis, A., Diessel, C.F.K., Littke, R. \& Robert, P., 1998. Organic petrology. Borntraeger, Berlin-Stuttgart, $704 \mathrm{pp}$.

Teichmüller, M., 1958. Rekonstruktion verschiedener Moortypen des Hauptflözes der Niederrheinischen
Braunkohle. Fortschritte in der Geologie von Rheinland und Westfalen 2, 599-612.

Teichmüller, M., 1989. The genesis of coal from the viewpoint of coal petrology. International Journal of Coal Geology 12, 1-87.

Ticleanu, N., Scradeanu, D., Popa, M., Milutinovici, S., Popa, R., Preda, I., Ticleanu, M., Savu, C., Diaconita, D., Barus, T., Petrescu, I., Dinulescu, C. \& Maftei, R., 1999. The relation between the lithotypes of Pliocene coals from Oltenia and their main quality characteristics. Bulletin of the Czech Geological Survey 74, 169-174.

Ważyńska, H. (Ed.), 1998. Palynology and palaeogeography of the Neogene in Polish Lowlands. Prace Państwowego Instytutu Geologicznego 160, 1-41.

Widera, M., 2007. Litostratygrafia i paleotektonika kenozoiku podplejstoceńskiego Wielkopolski [Lithostratigraphy and palaeotectonics of the sub-Pleistocene Cenozoic of Wielkopolska]. Adam Mickiewicz University Press, Poznań, $224 \mathrm{pp}$.

Widera, M., 2010. The morphology of fossil pebbles as a tool for determining their transport processes (Koźmin South lignite open-cast pit, central Poland). Annales Societatis Geologorum Poloniae 80, 315-325.

Widera, M., Ćwikliński W. \& Karman R., 2008. Cenozoic tectonic evolution of the Poznań-Oleśnica Fault Zone, central-western Poland. Acta Geologica Polonica 58, 455-471.

Widera, M. \& Hałuszczak, A., 2011. Stages of the Cenozoic tectonics in central Poland: examples from selected grabens. Zeitschrift der Deutschen Gesellschaft für Geowissenschaften 162, 203-214.

Widera, M., Jachna-Filipczuk, G., Kozula, R. \& Mazurek, S., 2007. From peat bog to lignite seam: a new method to calculate the consolidation coefficient of lignite seams, Wielkopolska region in central Poland. International Journal of Earth Sciences 96, 947-955.

Widera, M. \& Kita A., 2007. Paleogene marginal marine sedimentation in central-western Poland. Geological Quarterly 51, 79-90.

Wolf, M., 1988. Torf und Kohle. [In:] Füchtbauer, H. (Ed.): Sedimente und Sedimentgesteine - Teil II. Schweizerbart, Stuttgart, 683-730.

Zieliński, T., 1995. Kod litofacjalny i litogenetyczny konstrukcja i zastosowanie [Lithofacies and lithogenetic code - construction and application] [In:] E. Mycielska-Dowgiałło \& J. Rutkowski (Eds): Badania osadów czwartorzędowych. Wybrane metody i interpretacja wyników [Investigation of Quaternary deposits. Results of some methods and interpretations]. Warsaw University Press, Warsaw, 220-235.

Manuscript received: 20 September 2011 Revision accepted: 10 January 2012 